J. Dairy Sci. 91:4673-4678

doi:10.3168/jds.2007-0910

(c) American Dairy Science Association, 2008.

\title{
Comfort Zone-Design Free Stalls: Do They Influence the Stall Use Behavior of Lame Cows?
}

\author{
N. B. Cook, ${ }^{1}$ M. J. Marin, R. L. Mentink, T. B. Bennett, and M. J. Schaefer \\ School of Veterinary Medicine, University of Wisconsin-Madison, Madison 53706-1102
}

\begin{abstract}
The behavior of 59 cows in 4 herds, each with Comfort Zone-design free stalls with dimensions suitable for 700-kg, mature Holstein dairy cows, was filmed for a 48-h period. Comparison was made between nonlame, slightly lame, and moderately lame cows on either rubber-crumb-filled mattress stall surfaces bedded with a small amount of sawdust (2 herds) or a Pack Mat design, which consisted of a rubber-crumb-filled mattress pad installed $5 \mathrm{~cm}$ below a raised rear curb, bedded with 5 to $8 \mathrm{~cm}$ of sand bedding ( 2 herds). All other stall design components were similar. Despite adequate resting space and freedom to perform normal rising and lying movements, lame cows on mattresses stood in the stall for $>2 \mathrm{~h}$ longer than nonlame cows. Although a significant increase in stall standing behavior was observed in lame cows on Pack Mat stalls, the mean (95\% confidence interval) standing time in the stall was only 0.7 (0 to 3.0$) \mathrm{h} / \mathrm{d}$ for nonlame cows and 1.6 (0 to 4.2 ) $\mathrm{h} / \mathrm{d}$ for moderately lame cows, which was less than the 2.1 (0 to 4.4 ), 4.3 (1.6 to 6.9 ), and 4.9 (2.5 to 7.3 ) h/d spent standing in the stall for nonlame, slightly lame, and moderately lame cows on mattresses, respectively. This observation supports the hypothesis that it is the nature of the stall surface that dictates changes in stall standing behavior observed in lame cows, rather than other components of stall design. The finding that only 5 to $8 \mathrm{~cm}$ of sand over a mattress pad provides most of the benefits of deep sand-bedded stalls, along with other advantages related to stall maintenance and manure handling, gives farmers another useful housing alternative with which to improve cow comfort and well-being.
\end{abstract}

Key words: sand, mattress, lameness, stall behavior

Received December 3, 2007.

Accepted August 25, 2008.

${ }^{1}$ Corresponding author: nbcook@wisc.edu

\section{INTRODUCTION}

Free-stall design, and its effect on the health and productivity of the dairy cow, has been the focus of much attention in recent years. Anderson (2003) led the way by improving our understanding of cow ergonomics and highlighted some of the major stall design faults that the dairy industry has tolerated up until recently. Greater awareness of dairy cow well-being has triggered the need to understand the impact of the components of the stall on the behavior of the dairy cow and associated effects on health and productivity.

Tucker (2003) performed a sequence of experiments using preference testing and switch-back studies in a controlled environment to examine the effect on cow behavior of each stall component including stall surface type (Tucker et al., 2003), amount of bedding (Tucker and Weary, 2004), bedding maintenance (Drissler et al., 2005), brisket locator use (Tucker et al., 2006), neck rail height and horizontal location (Tucker et al., 2005), and stall width and length (Tucker et al., 2004). It was apparent from these studies that dairy cows prefer stalls with softer surfaces (deep sawdust or sand rather than rubber-crumb-filled mattresses), lie in stalls with rubber-crumb-filled mattresses longer when they are deep bedded with sawdust, lie down longer on deep loose-bedded surfaces that are level with the rear curb rather than concave, prefer stalls without a brisket locator compared with those with a board 20 $\mathrm{cm}$ high, stand more with all 4 feet on the platform and perch with the front 2 feet in the stall and the rear feet in the alley less in stalls with higher neck rails located further away from the rear curb, and lie down longer in wider stalls compared with the standard width of 106 $\mathrm{cm}$, which are commonplace on many North American dairy farms.

Despite our improved awareness of the effect of stall design on the behavior of the dairy cow, and an acceptance by many that different sizes of stall are required to meet the needs of dairy cows of different maturity, body size, and stage of lactation (Anderson, 2003; Cook and Nordlund, 2005), concerns exist over the amount of manure contamination on stall beds associated with larger dimensions and greater freedom of movement. Antago- 
nists rightly point out that the differences in lying time observed by Tucker (2003) were relatively small between treatments, of the order of $1.5 \mathrm{~h} / \mathrm{d}$, with many of the lowest lying times still exceeding $12 \mathrm{~h} / \mathrm{d}$, suggested by some as the required daily resting period for a dairy cow (Jensen et al., 2005; Munksgaard et al., 2005).

We suggested that the greatest impact of poor stall design may not manifest when the behavior of only nonlame cows is observed. The effect of stall design deficits on lame cows may be of much greater significance. Cook et al. (2004) demonstrated that lame cows housed in barns with rubber-crumb-filled mattress free stalls stood longer in the stalls, 2 to 3 times longer than nonlame cows, depending on the severity of lameness, had fewer stall use sessions per day, and lay down for less time than nonlame cows. In contrast, lame cows housed in similar barns with deep sand-bedded stalls had no significant change in stall use behavior. Cook and Nordlund (accepted) suggested that deep sand bedding facilitates the rising and lying movements of dairy cows that are lame, allowing them to maintain normal resting patterns, and this may explain, at least in part, the much lower prevalence of lameness observed in sand stalls compared with mattress stalls (Cook, 2003; Espejo et al., 2006). Indeed, a recent study demonstrated an improvement in hoof lesion score after $21 \mathrm{wk}$ in cows bedded on sand compared with cows on straw bedding (Norring et al., 2008). Sand bedding may reduce the development of new cases of lameness, although as yet there are no published data to confirm this.

Nevertheless, problems exist in managing and maintaining the surface of deep sand bedded stalls (Drissler et al., 2005), and handling sand-laden manure is challenging. The possibility exists that improved stall designs, which provide for greater freedom of movement in association with mattress stall surfaces, may allow for improved stall use by lame cows in the absence of a change in the type of surface. For example, small resting areas, low divider rails $(<0.34 \mathrm{~m})$, limited lunge space, high brisket locators $(>15 \mathrm{~cm})$, and high $(>16$ $\mathrm{cm})$ or low $(<15 \mathrm{~cm})$ rear curbs were related to an increased risk of lameness or claw horn lesions (Leonard et al., 1994; Philipot et al., 1994; Faull et al., 1996; Haskell et al., 2006; Barker et al., 2007; Espejo and Endres, 2007).

This study had 2 main aims. The first was to determine if mattress free stalls with improved dimensions and freedom of movement allowed lame cows to exhibit similar stall use behavior to nonlame cows. The second aim was to measure the stall use behavior of cows in stalls with identical stall dimensions with 5 to $8 \mathrm{~cm}$ of sand over a rubber-crumb-filled mattress pad to determine if the combination could yield similar benefits for lame cows as deep sand beds.

\section{MATERIALS AND METHODS}

\section{Herd Selection and Housing}

Four herds ranging in size from 70 to 158 cows, with rolling herd average milk production ranging from 10,005 to $12,252 \mathrm{~kg}$ housed in free-stall barns built within the last $3 \mathrm{yr}$ by one local builder using a combination of stall design features collectively known as the "Comfort Zone" (Promat Ltd., Woodstock, Ontario, Canada) were used in the study. All cows were milked twice daily and barns had drive-through feeding and 2-row pen configurations. Fresh TMR was delivered once daily, timed to coincide with return of the cows to the pen from the morning milking. The pens chosen for filming varied in size from 48 to 87 stalls between farms. All stalls had wide divider loops with an interior diameter of $0.89 \mathrm{~m}$ (Y2K divider loop, Artex Fabricators Ltd., Langley, British Columbia, Canada), located $1.22 \mathrm{~m}$ apart on center. Stalls were $2.9 \mathrm{~m}$ long and plastic Poly Pillow (Promat Ltd., Woodstock, Ontario, Canada) brisket locators, measuring $13 \mathrm{~cm}$ high, were located $1.78 \mathrm{~m}$ from the rear curb. Neck rails were located 1.27 $\mathrm{m}$ above the stall surface and $1.73 \mathrm{~m}$ from the rear curb from a horizontal point vertically above the rear lip of the curb. In 2 barns, the stall surface comprised a rubber-crumb-filled mattress (Pasture Mat, Promat Ltd.), bedded with a small amount ( $<1 \mathrm{~cm}$ depth) of sawdust (MAT). Fresh bedding was added twice weekly to stalls in each of these herds, and used only to absorb moisture rather than to add cushion to the surface. In the other 2 barns, the stall surface consisted of a similar rubber-crumb-filled mattress pad located $5 \mathrm{~cm}$ below a raised rear curb. This "Pack Mat" design allowed for the maintenance of 5 to $8 \mathrm{~cm}$ of sand bedding on top of the mattress pad (PACK). Sand bedding was groomed each milking and refreshed weekly.

\section{Cow Selection}

On the day before filming, each herd was visited and the high-yielding or early-lactation mixed-parity group of cows was locomotion scored (LMS) as cows exited the milking parlor using a 4-point scale described by Nordlund et al. (2004), where $1=$ nonlame, 2 = slightly lame, 3 = moderately lame, and $4=$ severely lame. A minimum of 15 cows on each farm were selected to include 5 cows in each of the first 3 LMS categories. Severely lame $(\mathrm{LMS}=4)$ cows were not included in the study. At the time of fresh feed delivery the following morning, cows were trapped in head-locks, spray marked with an identifying number, and photographed to aid video tracking at least $2 \mathrm{~h}$ before the start of filming. Cows were released from head-locks within $45 \mathrm{~min}$, and the LMS recorded the previous day was 
confirmed and adjusted if necessary. Parity, LMS, DIM, and most recent DHIA-recorded daily milk weight were used as covariates in the statistical modeling.

\section{Filming Methodology}

Herds were filmed in May 2005 (1 MAT herd), March 2006 (1 PACK herd), and May 2006 (1 PACK and 1 MAT herd), avoiding periods of summer heat stress. Average daily temperature was captured during the filming period so that mean ambient temperature was available as a covariate for the analysis. Stocking density on the day of filming was recorded and varied between farms from 0.89 to 1.12 cows per stall.

Methodology for video capture and tracking of individual marked cows was described elsewhere (Cook et al., 2004). Digital camcorders (Sony DCRTRV900 miniDV video camera, Sony Corp., New York, NY) were used to record $1 \mathrm{~s}$ of activity every $30 \mathrm{~s}$ on the long-play setting for a 48 -h period.

Time spent by each cow feeding (head over the feed curb) and drinking (head over the waterer), standing in an alley, standing in a stall (which included standing with all 4 feet in the stall and perching with just the front 2 feet in the stall), lying in a stall, and time spent out of the pen while milking were recorded for each cow, along with the duration of each lying bout. Average time out of the pen milking varied widely between the farms (from 1.6 to $4.4 \mathrm{~h} / \mathrm{d}$ ), and the mean (SE) time spent milking for MAT herds was almost $1 \mathrm{~h}$ longer than for PACK herds $(3.0 \pm 0.29$ compared with $2.1 \pm$ $0.17 \mathrm{~h} / \mathrm{d}$ ). To fairly represent the magnitude of the true effect of stall type on stall usage patterns, the analyses were performed on both real-time outcomes converted to a 24-h period, and activity times converted to hours per day within a 24-h period, standardizing all milking times for each cow to $2 \mathrm{~h} / \mathrm{d}$ using the proportion of time in the pen performing each activity.

\section{Statistical Analysis}

Activity time budgets were created using the MEANS procedure of SAS (version 9.1, SAS Institute Inc., Cary, $\mathrm{NC})$ to estimate time lying, time standing in the alley (including drinking), time feeding, and time spent standing in the stall. Mixed effect models were created to investigate differences in cow behavior (time spent lying down in the stall, standing in the stall, standing in the alley, standing feeding, and average lying bout duration) between the 2 different stall types (MAT and PACK) by LMS. Based on review of residual plots, all variables were $\log$-transformed to ensure an approximate normal distribution.
Analysis of covariance was performed for each behavior using PROC MIXED in SAS, with stall type and LMS for each cow forced into all models. Cow-level fixed effects including parity, most recent DHIA-recorded milk yield, and DIM, and herd-level fixed effects including pen stocking density and mean ambient temperature on the day of filming were included as covariates. Stall type, parity, and LMS were included in the classes statement along with a random effect for farm. Nonsignificant fixed effects $(P>0.05)$ were removed by the process of stepwise backward elimination. Biologically plausible 2-way interactions were examined from the resultant model and retained if significant $(P<$ 0.05 ). Differences recorded between least squares mean activities for each LMS and stall type combination were tested using Fisher's protected least significant difference with a level of significance of $P<0.05$. Where back-transformed least squares means are presented, 95\% confidence intervals (CI) are used rather than a standard error term. Where the confidence limits overlap $0 \mathrm{~h}$, they are truncated to a lower limit of zero to reflect biologically plausible variance in the data.

\section{RESULTS}

Time budgets were available for 30 cows in the 2 MAT herds, with mean (SE) parity of $2.5 \pm 0.25$, and for 29 cows in the 2 PACK herds with a mean parity of $2.7 \pm 0.31$. Mean DIM for both groups was $188 \pm$ 20.2. Seven cows recruited at the time of filming could not be tracked for the entire 48-h filming period. As similar model results were achieved with both real-time activities and activity times corrected to a 2-h milking, results from the corrected time models will be presented to more appropriately represent the true effect of stall type on stall use behavior, uninfluenced by differences in milking time. The mean 24 -h time budgets are presented in Figure 1 by LMS and stall type. The most notable effect of stall type was the change in time spent standing in the stall by LMS, and associated changes in lying behavior.

A stall type effect was observed for time spent standing in the stall $(P=0.027)$ and average lying bout duration $(P=0.045)$. Back-transformed least squares mean time standing in a stall was $1.07 \mathrm{~h} / \mathrm{d}$ for cows on PACK stalls, compared with $3.52 \mathrm{~h} / \mathrm{d}$ for cows on MAT stalls (Table 1). Although the effect of stall type was not significant for lying time $(P=0.127)$, cows on MAT stalls had significantly shorter $(P<0.045)$ mean ( $95 \%$ CI ) lying bout durations $(0.95 ; 0$ to $2.20 \mathrm{~h} / \mathrm{d})$ than cows on PACK stalls (1.32; 0.07 to 2.57$)$.

There was an effect of LMS on stall standing behavior $(P<0.001$; Table 2$)$, in the absence of a stall type by LMS interaction $(P=0.942)$. Stall standing 


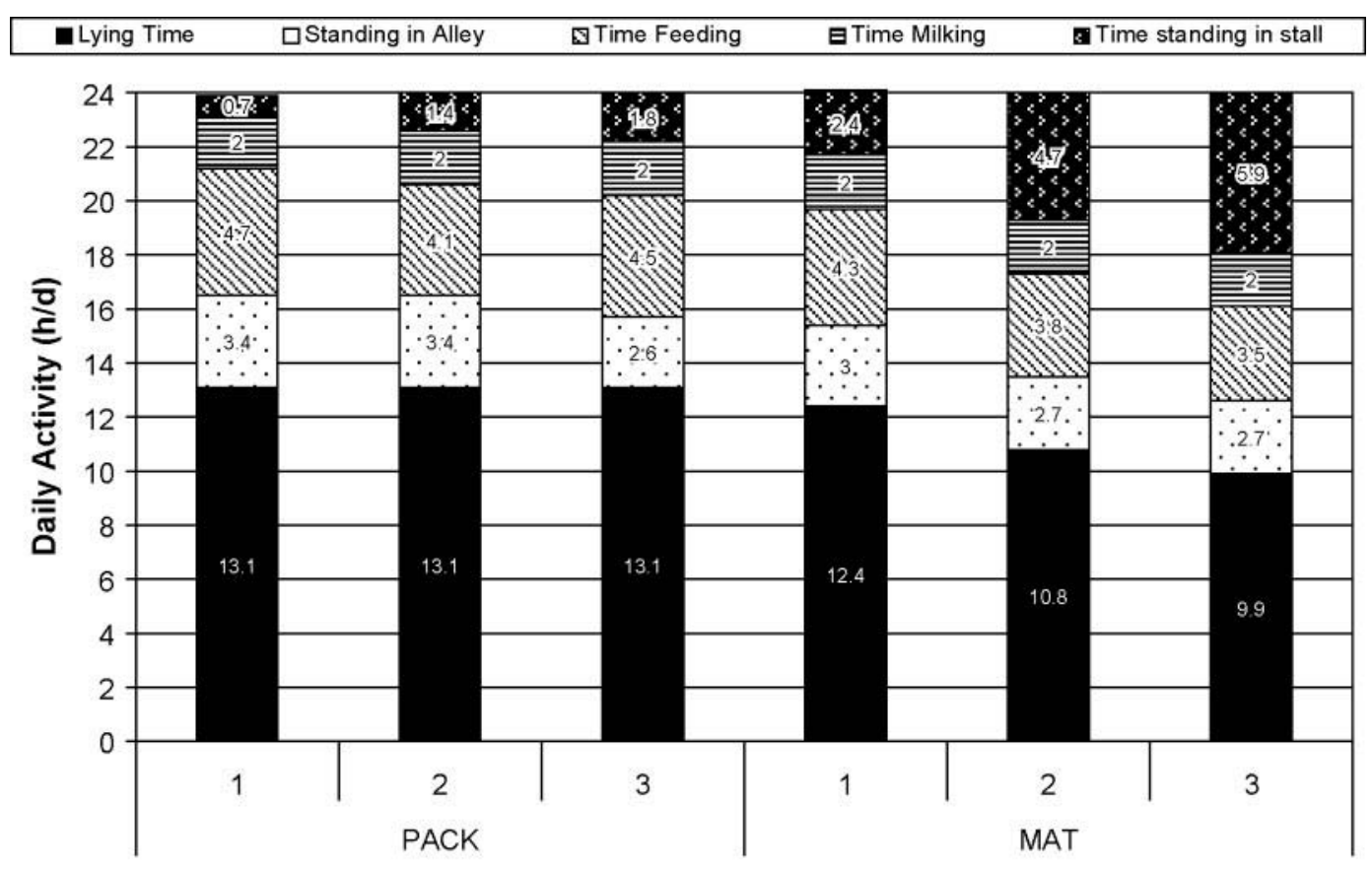

Locomotion Score (1 to 3$)$

Figure 1. Mean activity times for lying, standing in the alley, feeding, milking, and standing in the stall by locomotion score category $(1=$ non-lame, $2=$ slightly lame, $3=$ moderately lame) compared between 30 cows in 2 MAT (rubber-crumb-filled mattress) herds $(\mathrm{n}=11$ score $1, \mathrm{n}=9$ score $2, \mathrm{n}=10$ score 3 ) and 29 cows in 2 PACK ( 5 to $8 \mathrm{~cm}$ of sand over a mattress pad) herds $(\mathrm{n}=10$ score $1, \mathrm{n}=11$ score $2, \mathrm{n}=8$ score 3 ). Daily activity (h/d) was calculated from the proportion of time spent in the pen not milking and standardized across $24 \mathrm{~h}$ to a $2 \mathrm{~h} / \mathrm{d}$ milking time for all cows.

behavior increased with LMS in cows housed in both MAT and PACK herds. Still, stall standing time for nonlame (LMS 1) cows on PACK stalls was significantly lower than for LMS 1 cows on MAT stalls $(0.65 \mathrm{~h} / \mathrm{d}$ on PACK stalls compared with $2.08, \mathrm{~h} / \mathrm{d}$ on MAT stalls), and although standing time increased by LMS for cows on PACK stalls up to $1.58 \mathrm{~h} / \mathrm{d}$ for LMS 3 cows, this was still numerically less than the stall standing time for LMS 1 cows on MAT stalls, and significantly less than the $4.91 \mathrm{~h} / \mathrm{d}$ for LMS 3 cows on MAT stalls $(P<$ $0.001)$.

There was no significant stall type or LMS effect on time spent standing in the alley and time feeding, but there was a parity effect for the latter $(P=0.036)$, with first-lactation heifers spending more time feeding than older parity groups. Mean time feeding (95\% CI) contrasts were significant between first-lactation (4.76; 3.61 to 5.91$) \mathrm{h} / \mathrm{d}$ and third-lactation $(3.67 ; 2.56$ to

Table 1. Back-transformed least squares mean activity (hours/day; $95 \%$ confidence limits in parentheses) for 29 cows housed on PACK ( 5 to $8 \mathrm{~cm}$ of sand over a mattress pad) stall surfaces compared with 30 cows housed on MAT (rubber-crumb-filled mattress) stall surfaces

\begin{tabular}{|c|c|c|c|c|}
\hline \multirow[b]{2}{*}{ Activity $^{1}$} & \multicolumn{2}{|c|}{ Stall type } & \multicolumn{2}{|c|}{$P$-value ${ }^{2}$} \\
\hline & MAT & PACK & Stall type & LMS \\
\hline Lying time & $10.37(9.07$ to 11.67$)$ & $12.91(11.61$ to 14.21$)$ & 0.127 & 0.128 \\
\hline Time standing up in stall & $3.52(1.69$ to 5.34$)$ & $1.07(0$ to 2.90$)$ & 0.027 & $<0.001^{3}$ \\
\hline Time standing up in alley & $2.06(0.32$ to 3.80$)$ & $2.49(0.75$ to 4.23$)$ & 0.409 & 0.295 \\
\hline Time feeding ${ }^{4}$ & $3.39(1.36$ to 5.43$)$ & $4.29(2.07$ to 6.51$)$ & 0.173 & 0.931 \\
\hline Mean duration of lying bout & $0.95(0$ to 2.20$)$ & $1.32(0.07$ to 2.57$)$ & 0.045 & 0.999 \\
\hline
\end{tabular}

${ }^{1}$ Activity times were standardized to a 24 -h time period with a $2 \mathrm{~h} / \mathrm{d}$ milking time for each cow.

${ }^{2} P$-values are for Type 3 tests of fixed effects from the mixed models for the effects of stall type and locomotion score (LMS).

${ }^{3}$ The interaction between stall type and LMS was not significant at $P=0.942$.

${ }^{4}$ A significant parity effect was observed for time feeding at $P=0.036$. 
Table 2. Back-transformed least squares mean for time spent standing in the stall (hours/day; 95\% confidence limits in parentheses) for 29 cows housed on PACK ( 5 to $8 \mathrm{~cm}$ of sand over a mattress pad) stall surfaces compared with 30 cows housed on MAT (rubber-crumb-filled mattress) stall surfaces, by locomotion score (LMS $)^{1}$

\begin{tabular}{lll}
\hline & \multicolumn{2}{c}{ Stall type } \\
\cline { 2 - 3 } LMS & \multicolumn{1}{c}{ MAT } & \multicolumn{1}{c}{ PACK } \\
\hline 1 & $2.08^{* \mathrm{a}}(0$ to 4.40$)$ & $0.65^{* \mathrm{a}}(0$ to 3.05$)$ \\
2 & $4.26^{* \mathrm{~b}}(1.64$ to 6.88$)$ & $1.2^{* \mathrm{~b}}(0$ to 3.53$)$ \\
3 & $4.91^{* \mathrm{~b}}(2.51$ to 7.31$)$ & $1.58^{* \mathrm{~b}}(0$ to 4.19$)$ \\
\hline
\end{tabular}

${ }^{\mathrm{a}, \mathrm{b}}$ Means within a column with different superscripts differ $(P<$ $0.05)$.

${ }^{1}$ Activity times were standardized to a 24 -h time period with a $2 \mathrm{~h} / \mathrm{d}$ milking time for each cow.

${ }^{*}$ Means within a row are significantly different $(P<0.05)$.

4.78) h/d, fourth-lactation ( $3.68 ; 2.45$ to 4.91$) \mathrm{h} / \mathrm{d}$ and fifth-lactation cows $(3.26 ; 1.99$ to 4.53$) \mathrm{h} / \mathrm{d}$.

\section{DISCUSSION}

Differences in stall standing behavior were documented in lame cows housed on different stall surfaces (Cook et al., 2004). Yet factors other than surface type are important considerations when investigating the effect of stall design on lameness and behavior. For example, Espejo and Endres (2007) found an association between brisket locator height and lameness, while Tucker et al. (2006) showed that the presence of a 20-cm-high brisket locator negatively affected the stall use behavior of nonlame cows. Although attempts were made to minimize stall design differences between the 12 herds in the study by Cook et al. (2004), it could be argued that factors other than stall base type may have influenced the results of that study. The availability of several recently constructed facilities with a uniform stall design, free of major obstructions to normal rising and lying movements, and with improved dimensions more suitable to the housing of large $(700 \mathrm{~kg})$ mature Holstein dairy cows, presented an opportunity to further investigate the effect of free-stall design and stall surface type on nonlame and lame cow behavior.

Although the improved stall design and dimensions in this study provided very respectable resting times in excess of $12 \mathrm{~h} / \mathrm{d}$ for nonlame dairy cows on both types of stall, there was a significant effect of surface type on the behavior of lame cows. Slightly lame and moderately lame cows stood in the MAT stalls for 4.3 and $4.9 \mathrm{~h} / \mathrm{d}$, respectively, whereas lying time was reduced. In PACK stalls, with 5 to $8 \mathrm{~cm}$ of sand over a rubbercrumb-filled mattress pad, nonlame cows stood in the stall for less than $0.7 \mathrm{~h} / \mathrm{d}$, and although stall standing time increased significantly to $1.6 \mathrm{~h} / \mathrm{d}$ in moderately lame cows, this was still less than the stall standing time of nonlame cows on MAT stalls $(2.1 \mathrm{~h} / \mathrm{d})$. Lame cows may have exercised a surface preference over the concrete alleys, because lying time was not significantly reduced in lame cows in PACK stalls, as has been suggested by Tucker et al. (2003). Nonetheless, the associated changes in lying behavior observed in lame cows in MAT stalls make this explanation less likely for this type of stall, suggesting that lame cows may have more difficulty rising or lying down than nonlame cows, leading to extended time spent standing in the stall. These data support Cook et al., (2004), and are consistent with the hypothesis put forward by Cook and Nordlund (accepted), that it is the nature of the interaction of the weight-bearing rear foot of the cow and the stall surface, and the pain associated with this interaction during rising and lying movements that influence the stall use behavior of lame cows. Of note in the current study is that some degree of significant change in stall standing behavior was observed in lame cows in both types of stall, but the behavioral challenges appear greater for cows on MAT stalls than on PACK stalls.

Cook et al. (2004) failed to show a significant difference in lying bout duration between sand and mattress stalls. But there was a significant difference in the distribution of long lying bouts, with cows on sand having a greater proportion of long bouts. In the current study, a significant effect was observed, with the average lying bout duration being 22 min longer for cows on PACK stalls $(1.32 \mathrm{~h})$ compared with cows on MAT stalls $(0.95$ h). The range in lying bout duration was similar to the 0.9 to $1.5 \mathrm{~h}$ reported by Tucker (2003) across a range of studies. Still, longer lying bouts may only be a sign of improved comfort when associated with greater total resting times (Tucker et al., 2004).

The amount of sawdust bedding used in the MAT herds in this study was insufficient to improve surface cushion. The amount of bedding on top of a mattress surface affected resting time (Tucker et al., 2004). Significant effects on the duration of lying were observed in situations where a large amount of bedding $(\sim 7.5$ $\mathrm{kg}$ ) was kept on the mattress surface using a bedding retainer. The PACK stall design, with a mattress pad installed below a raised rear curb allowed for the retention of bedding material in the stall. The producer may decide which type of bedding to use. Still, the use of sand rather than an organic bedding material carries with it udder health benefits (Zdanowicz et al., 2004; Cook and Reinemann, 2007). It would appear that only 5 to $8 \mathrm{~cm}$ of sand over a mattress pad can result in a stall that can be used successfully by lame cows. Although the initial cost of the PACK stall is greater than for a deep loose-bedded sand stall (approximately $\$ 100$ per stall more), this may be offset by a $50 \%$ reduction in sand usage, which at typical sand costs would mean 
that the investment would be paid off over $2 \mathrm{yr}$. In addition, the benefits of improved ease of management of the bedding surface and the addition of less sand to the manure cannot be overlooked.

\section{CONCLUSIONS}

Improved design and dimensions of stalls fitted with rubber-crumb-filled mattresses did not improve the stall use behavior of lame cows, but did provide resting times in excess of $12 \mathrm{~h} / \mathrm{d}$ for nonlame cows. Despite the provision of ample lunge and resting space, room to plant the front leg forward as the cow rises, and space below and behind the neck rail, lame cows were observed standing in free stalls with a rubber-crumbfilled mattress for prolonged periods of time, to the detriment of resting behavior. This observation supports the hypothesis that it is the nature of the stall surface that dictates changes in stall standing behavior observed in lame cows, rather than other components of stall design. The finding that only 5 to $8 \mathrm{~cm}$ of sand over a mattress pad provides most of the benefits of deep sand-bedded stalls, minimizing the changes in stall standing time observed in lame cows, along with other benefits related to stall maintenance and manure handling, gives farmers a useful housing alternative with which to improve cow comfort and well-being.

\section{ACKNOWLEDGMENTS}

This study was supported by L and L Sales and Services Inc. (Kaukauna, WI), ProMat Ltd., and Artex Fabricators Ltd. (responsible for the Comfort Zone free stalls), and by the members of the UW Cow Comfort and Well-Being Consortium, which includes Zinpro Performance Minerals (Minneapolis, MN), Pfizer Animal Health (New York, NY), Vita Plus Corporation (Madison, WI), and AgSource Cooperative Services (Verona, WI). M. J. Schaefer was funded by a Merck Merial Summer Training Scholarship in 2006. The authors would like to thank the farmers involved in the study for their patience.

\section{REFERENCES}

Anderson, N. 2003. Dairy cattle behavior: Cows interacting with their workplace. Pages 10-22 in Proc. 36th Annual Convention Am. Assoc. Bovine Pract., Columbus, OH.

Barker, Z. E., J. R. Amory, J. L. Wright, R. W. Blowey, and L. E. Green. 2007. Management factors associated with impaired locomotion in dairy cows in England and Wales. J. Dairy Sci. 90:3270-3277.

Cook, N. B. 2003. Prevalence of lameness among dairy cattle in Wisconsin as a function of housing type and stall surface. J. Am. Vet. Med. Assoc. 223:1324-1328.

Cook, N. B., T. B. Bennett, and K. V. Nordlund. 2004. Effect of free stall surface on daily activity patterns in dairy cows, with relevance to lameness prevalence. J. Dairy Sci. 87:2912-2922.
Cook, N. B., and K. V. Nordlund. 2005. An update on dairy cow freestall design. Bovine Pract. 39:29-36.

Cook, N. B., and K. V. Nordlund. The influence of the environment on dairy cow behavior, claw health and herd lameness dynamics. Vet. J. doi:10.1016/j.tvjl.2007.09.016. In press.

Cook, N. B., and D. Reinemann. 2007. A tool box for assessing cow, udder and teat hygiene. Pages 31-43 in 46th Natl. Mastitis Counc. Mtg. Proc. San Antonio, Texas. Natl. Mastitis Counc. Inc., Madison, WI.

Drissler, M., M. Gaworski, C. B. Tucker, and D. M. Weary. 2005. Freestall maintenance: Effects on lying behavior of dairy cattle. J. Dairy Sci. 88:2381-2387.

Espejo, L. A., and M. I. Endres. 2007. Herd-level risk factors for lameness in high-producing Holstein cows housed in freestall barns. J. Dairy Sci. 90:306-314.

Espejo, L. A., M. I. Endres, and J. A. Salfer. 2006. Prevalence of lameness in high-producing Holstein cows housed in freestall barns in Minnesota. J. Dairy Sci. 89:3052-3058.

Faull, W. B., J. W. Hughes, M. J. Clarkson, D. Y. Downham, F. J. Manson, J. B. Merritt, R. D. Murray, W. B. Russell, J. E. Sutherst, and W. R. Ward. 1996. Epidemiology of lameness in dairy cattle: The influence of cubicles and indoor and outdoor walking surfaces. Vet. Rec. 139:130-136.

Haskell, M. J., L. J. Rennie, V. A. Bowell, M. J. Bell, and A. B. Lawrence. 2006. Housing system, milk production, and zerograzing effects on lameness and leg injury in dairy cows. J. Dairy Sci. 89:4259-4266.

Jensen, M. B., L. J. Pedersen, and L. Munksgaard. 2005. The effect of reward duration on demand functions for rest in dairy heifers and lying requirements as measured by demand functions. Appl. Anim. Behav. Sci. 90:207-217.

Leonard, F. C., J. M. O'Connell, and K. J. O'Farrell. 1994. Effect of different housing conditions on behaviour and foot lesions in Friesian heifers. Vet. Rec. 134:490-494.

Munksgaard, L., M. B. Jensen, L. J. Pedersen, S. W. Hansen, and L. Matthews. 2005. Quantifying behavioural priorities-Effects of time constraints on behavior of dairy cows. Appl. Anim. Behav. Sci. 92:3-14

Nordlund, K. V., N. B. Cook, and G. R. Oetzel. 2004. Investigation strategies for laminitis problem herds. J. Dairy Sci. 87(E Suppl.):E27-E35.

Norring, M., E. Manninen, A. M. de Passille, J. Rushen, L. Munksgaard, and H. Saloniemi. 2008. Effects of sand and straw bedding on the lying behavior, cleanliness, and hoof and hock injuries of dairy cows. J. Dairy Sci. 91:570-576.

Philipot, J. M., P. Pluvinage, I. Cimarosti, P. Sulpice, and F. Bugnard. 1994. Risk factors of dairy cow lameness associated with housing conditions. Vet. Res. 25:244-248.

Tucker, C. B. 2003. The effects of free stall surfaces and geometry on dairy cattle behavior. PhD thesis. The University of British Columbia, Vancouver, Canada.

Tucker, C. B., and D. M. Weary. 2004. Bedding on geotextile mattresses: How much is needed to improve cow comfort? J. Dairy Sci. 87:2889-2895.

Tucker, C. B., D. M. Weary, and D. Fraser. 2003. Effects of three types of freestall surfaces on preferences and stall usage by dairy cows. J. Dairy Sci. 86:521-529.

Tucker, C. B., D. M. Weary, and D. Fraser. 2004. Free-stall dimensions: Effects on preference and stall usage. J. Dairy Sci. 87:12081216.

Tucker, C. B., D. M. Weary, and D. Fraser. 2005. Influence of neck rail placement on freestall preference, use and cleanliness. J. Dairy Sci. 88:2730-2737.

Tucker, C. B., G. Zdanowicz, and D. M. Weary. 2006. Brisket boards reduce freestall use. J. Dairy Sci. 89:2603-2607.

Zdanowicz, M., J. A. Shelford, C. B. Tucker, D. M. Weary, and M. A. G. von Keyserlingk. 2004. Bacterial populations on teat ends of dairy cows housed in freestalls and bedded with either sand or sawdust. J. Dairy Sci. 87:1694-1701. 